University of Nebraska - Lincoln DigitalCommons@University of Nebraska - Lincoln

USDA National Wildlife Research Center - Staff U.S. Department of Agriculture: Animal and Plant Publications Health Inspection Service

2014

\title{
Understory fern community structure, growth and spore production responses to a large-scale hurricane experiment in a Puerto Rico rainforest
}

Joanne M. Sharpe

Sharplex Services, joannesharpe@juno.com

Aaron B. Shiels

University of Puerto Rico-Rio Piedras, Aaron.B.Shiels@aphis.usda.gov

Follow this and additional works at: https://digitalcommons.unl.edu/icwdm_usdanwrc

Part of the Life Sciences Commons

Sharpe, Joanne M. and Shiels, Aaron B., "Understory fern community structure, growth and spore production responses to a largescale hurricane experiment in a Puerto Rico rainforest" (2014). USDA National Wildlife Research Center - Staff Publications. 1584. https://digitalcommons.unl.edu/icwdm_usdanwrc/1584

This Article is brought to you for free and open access by the U.S. Department of Agriculture: Animal and Plant Health Inspection Service at DigitalCommons@University of Nebraska - Lincoln. It has been accepted for inclusion in USDA National Wildlife Research Center - Staff Publications by an authorized administrator of DigitalCommons@University of Nebraska - Lincoln. 


\title{
Understory fern community structure, growth and spore production responses to a large-scale hurricane experiment in a Puerto Rico rainforest
}

\author{
Joanne M. Sharpe ${ }^{\mathrm{a}, *}$, Aaron B. Shiels ${ }^{\mathrm{b}, 1}$ \\ a Sharplex Services, PO Box 499, Edgecomb, ME 04556, USA \\ ${ }^{\mathrm{b}}$ Institute for Tropical Ecosystems Studies, University of Puerto Rico-Rio Piedras, PO Box 70377, San Juan, PR 00936-8377, USA
}

\section{A R T I C L E I N F O}

\section{Article history:}

Available online 11 February 2014

\section{Keywords:}

Canopy litter

Cyathea borinquena

Ecological resilience

Invasive pioneer fern

Tropical understory light

Thelypteris deltoidea

\begin{abstract}
A B S T R A C T
Ferns are abundant in most rainforest understories yet their responses to hurricanes have not been wellstudied. Fern community structure, growth and spore production were monitored for two years before and five years after a large-scale experiment that simulated two key components of severe hurricane disturbance: canopy openness and debris deposition. The canopy was opened by cutting branches above $3 \mathrm{~m}$ and the fallen leaf and woody debris was either added to or removed from the forest floor resulting in four treatments that were replicated three times in a factorial design. Of the 16 fern species observed during the experiment 12 were present before treatments were applied. All but two of the 16 species had densities $<250 \mathrm{ha}^{-1}$; Thelypteris deltoidea $\left(2258 \mathrm{ha}^{-1}\right)$ and Cyathea borinquena $\left(1521 \mathrm{ha}^{-1}\right)$ were by far the most common ferns. Under simulated hurricane conditions (open canopy and debris deposition) abundance levels for both $T$. deltoidea and $C$. borinquena were highly resilient and returned to pre-disturbance conditions within three years; therefore the resident (non-pioneer) fern species continued to dominate after disturbance. However, several other variables had increasing or decreasing responses that had not returned to pre-treatment levels by the fifth and final year of the experiment. Four pioneer species appeared in low abundance almost immediately after the canopy was opened, including three native species that spread via spore germination and the invasive Nephrolepis brownii that spread by runners. Debris deposition resulted in high mortality for 7 of 12 fern species, with $C$. borinquena among the species little affected and increases in recruitment following mortality of $T$. deltoidea under open canopy. Individuals of both $T$. deltoidea and $C$. borinquena responded to higher light levels with growth spurts reflected in up to two- to three-fold increases in leaf production and emergence of longer leaves. Spore production rates for both $T$. deltoidea and $C$. borinquena had been low in the undisturbed pre-treatment forest, but more than doubled in the years that followed canopy opening. Hurricane impacts to this tropical forest alter the fern community by (1) debris deposition burying individuals and initially reducing some population sizes, and (2) canopy openness overwhelming the negative effects of debris deposition and stimulating growth and reproduction that can last $\geqslant 5$ years. Changes resulting from hurricane disturbance that affect the ferndominated herbaceous layer may ultimately influence structure and function of the long-term understory plant community and consequently the habitat of litter- and soil-dwelling organisms.
\end{abstract}

(c) 2014 Elsevier B.V. All rights reserved.

\section{Introduction}

Very large hurricanes pass over the Luquillo Experimental Forest (LEF) in northeastern Puerto Rico every 50-60 years on average (Scatena and Larsen, 1991). Researchers from the Luquillo

\footnotetext{
* Corresponding author.

E-mail address: joannesharpe@juno.com (J.M. Sharpe).

1 Present address: USDA, National Wildlife Research Center, Hawaii Field Station, PO Box 10880, Hilo, HI 96721, USA
}

Long-Term Ecological Research (LTER) program monitored forest responses after the two most recent severe hurricanes in the LEF, Hugo in 1989 (e.g. Brokaw and Walker, 1991; Zimmerman et al., 1996) and Georges in 1998 (e.g. Canham et al., 2010; Heartsill Scalley et al., 2010). Woody plant responses to hurricanes have been evaluated in a variety of ways (reviewed in Lugo, 2008) and such studies have provided the basis for models used to evaluate tropical forest dynamics (Uriarte et al., 2005; Comita et al., 2009) and effects of different levels of wind damage on tree species (Canham et al., 2010). Though protected from hurricane winds and driving 
rain by canopy layers above, forest floor organisms experience indirect effects of a hurricane such as changes in the light environment (Fernández and Fetcher, 1991; Scatena et al., 1996) and increased volumes of litter debris derived from damage to the canopy layer (Ostertag et al., 2003; Beard et al., 2005). However, the forest floor plant community, except for the often ephemeral seedlings of shrubs and trees, has largely been ignored by hurricane researchers (but see Scatena et al., 1996; Chinea, 1999; Royo et al., 2011). Ferns can be very long-term residents of the forest floor and although a proportionally small component of rainforest biomass, fern species counts are often equivalent to the number of tree species in the same tropical forest (Gentry and Dodson, 1987). Furthermore, ferns comprise a significant part of the low understory canopy that provides shade and nutrients to the litter layer and soil surface habitats where other organisms (e.g. invertebrates and fungi) that are vital to decomposition and biogeochemical cycling reside (Willig et al., 2012).

Despite the great richness and ubiquity of ferns in rainforest understories (Gentry and Dodson, 1987; Poulsen and Balslev, 1991), the importance of their responses to severe rainforest perturbations and effects on other elements of the ecosystem are just beginning to be recognized (e.g. landslides, Walker et al., 2010; hurricanes, Royo et al., 2011). Ferns can have a significant role in shaping the trajectory of forest development after a disturbance (Walker and Sharpe, 2010); thicket-forming fern species can increase soil organic matter (Walker, 1994) or physically inhibit forest recovery on landslides (Walker et al., 2010, 2013). Such filtering effects, where fern species alter plant communities and/or ecosystem processes, have been reported widely: Polystichum montevidense and Blechnum penna-marina in Argentina (Enrico et al., 2004); Pteridium arachnoideum in Brazil (Silva Matos and Belinato, 2010); Blechnum discolor in New Zealand (Dearden and Wardle, 2008); and Sticherus bifidus, Gleicheniella pectinata and Cyathea arborea in Puerto Rico (Walker, 1994; Walker et al., 2010). Studies of the magnitude and timing of responses to recent hurricanes in Puerto Rico have shown some of the potential impacts on ferns. In an observational study in mangrove forest, the common fern Acrostichum danaeifolium increased leaf production and spore production by more than $50 \%$ immediately following the passage of Hurricane Georges (Sharpe, 2010b). Observations of the LEF following Hurricane Hugo showed that some ferns responded with an initial decrease in abundance (Scatena et al., 1993) followed by slight increases within five years (Chinea, 1999). Royo et al. (2011) found that abundance and biomass of several fern species had increased at least $200 \%$ in the decade after Hurricane Hugo and remained at high levels after Hurricane Georges and through the end of their study (2010) when ferns comprised 60\% of non-arborescent plant abundance and biomass. Given the emerging understanding that some ferns can physically affect successional trajectories within an ecosystem after disturbance (Walker and Sharpe, 2010), it is important to experimentally expose the functional basis for such fern impacts.

Few studies have attempted large-scale forest manipulations to simulate hurricane effects. However, at the temperate Harvard Forest LTER (1990-1995), trees were uprooted to simulate the effects of the strong winds of an earlier 1938 hurricane (Cooper-Ellis et al., 1999). A $100 \%$ increase in cover of Dennstaedtia punctilobula, a temperate fern that inhibits seed and seedling development (George and Bazzaz, 2003), occurred within four years of initiating the hurricane simulation experiment (Cooper-Ellis et al., 1999). After observing the responses of forest trees following Hurricanes Hugo and Georges, the Luquillo LTER program began a large-scale experiment in the LEF of Puerto Rico that was designed to independently assess two main structural impacts of a hurricane on the forest: (1) canopy damage resulting in openings that allowed increased levels of light to reach forest layers below, and (2) subsequent deposition of debris from the canopy onto the forest floor. Thus, in our hurri- cane simulation experiment in the LEF, our focus has shifted from the well-studied direct effects at the tree canopy interface (e.g., Burslem et al., 2000; Brokaw et al., 2004) to the indirect effects on ecosystem processes and organisms of the forest floor and soil interface. The experiment was designed to test the direction and nature of responses of many processes and organisms (e.g. litter invertebrates: Richardson et al., 2010; woody plants (seedlings and adults) and graminoids, Shiels et al., 2010; and others described in this issue) to the separate and interactive effects of canopy openness and debris deposition. Here we focus on the treatment effects to the fern community.

Resilience theory has been useful in describing responses to hurricane disturbance in rainforest ecosystems (e.g. Zimmerman et al., 1996; Lugo et al., 2002; Imbert and Portecop, 2008; Lugo et al., 2012). Ecological resistance and resilience, originally defined by Holling (1973), refer to the ability of an ecosystem either to not change substantially in function or structure in response to a disturbance (resistance) or to change but then recover to pre-disturbance conditions (resilience). Resilience and resistance are assessed based on several factors including direction of change, amplitude of response and time to recovery (Walker, 2012). Although many studies have discussed resilient properties of ecosystems (e.g. Zimmerman et al., 1996; Melendez-Ackerman et al., 2003; Ostertag et al., 2003; Beard et al., 2005; Watson and Estes, 2011), few studies have quantified resilience (but see Washington-Allen et al., 2008). Resilience theory can serve as a lens through which to understand how fern responses to canopy opening and debris deposition compare to responses of other organisms and ecosystem processes following hurricane disturbance (Lugo et al., 2012).

The growth habit of ferns of the tropical rainforest floor is particularly well-suited to rapidly respond to experimental manipulations and natural disturbance. Most understory ferns of the LEF are long-lived perennials that produce leaves sequentially over time, at species-specific rates of about two to five leaves per year (Sharpe, 1997, 2010a). After experiencing a change in environmental conditions, an individual fern can rapidly shift its rate of leaf production as well as the length and type of leaves (spore-bearing vs. purely photosynthetic) that subsequently emerge (Halleck et al., 2004; Sharpe, 2010a,b; Sharpe and Mehltreter, 2010). Here we assess the effects of canopy opening and debris deposition in this hurricane simulation experiment in the LEF on fern community structure, growth and spore production by asking the following questions: (1) How does opening the canopy and/or depositing canopy debris on the ground affect species richness and abundance of the forest floor fern community? (2) What changes occur in fern growth processes (reflected by leaf count per plant and length of longest leaf) and rates of spore production in response to specific changes in the fern environment? (3) To what extent can changes in fern abundance, growth and spore production under simulated hurricane conditions be assessed after five years using elements of resilience theory?

\section{Methodology}

\subsection{Study area}

This study was conducted $<1 \mathrm{~km}$ from the El Verde Field Station (EVFS; $18^{\circ} 20^{\prime} \mathrm{N}, 65^{\circ} 49^{\prime} \mathrm{W}$ ) in the LEF, northeastern Puerto Rico. The LEF is a wet tropical forest and is divided into four general vegetation zones along an altitudinal gradient. The study site was located in mature forest in the lowermost and dominant vegetation zone, the tabonuco forest (subtropical wet forest in the Holdridge System; Ewel and Whitmore, 1973), where motillo (Sloanea berteriana), sierra palm (Prestoea montana), and tabonuco (Dacryodes 
excelsa) are the dominant tree species. Mean annual rainfall at the site is $3500 \mathrm{~mm}$ (Zimmerman et al., 2007), elevation is in the range of 340-485 $\mathrm{m}$ a.s.l, and the terrain is steep (24\% average slope) and rocky with boulders and stones covering approximately $25 \%$ of the soil surface (Soil Survey Staff, 1995; Shiels et al., 2010). The experimental plots were located on upper slopes and ridges, avoiding the more variable steep slopes and riparian areas of the forest. The two most recent severe hurricanes passing over the LEF preceding the initiation of the experiment were Hurricane Hugo (category 4 on the Saffir-Simpson hurricane scale) in September 1989, and Hurricane Georges (category 3) in September 1998.

\subsection{Experimental design}

Detailed descriptions of the study site, including a map of plot placement and experimental design, can be found in Richardson et al. (2010) and Shiels and González (2014). Briefly, the canopy trimming experiment (CTE) followed a completely randomized block design where each of three blocks (A, B and C) had four $30 \times 30 \mathrm{~m}$ plots established (12 plots in total). Two manipulations were performed: (1) branches and leaves removed from canopy (trimmed) and (2) branch segments and leaves deposited on the forest floor (debris). Each plot within a block was randomly assigned to one of the four treatments ( $n=3$ for each treatment): ( 1 ) No trim + no debris, where neither the canopy nor the forest floor were altered; (2) Trim + no debris where the canopy was trimmed and the debris from the trimming was removed from the plot; (3) No trim + debris, where the canopy was unaltered, but debris from the Trim + no debris treatment (2) was weighed and deposited on the forest floor; and (4) Trim + debris, where the canopy was trimmed and debris from the trimming was weighed and then re-distributed on the forest floor below.

In total, six plots had their canopies trimmed (two per block: one Trim + debris and one Trim + no debris treatment) to simulate forest structure observed after earlier hurricanes in the LEF (Brokaw and Grear, 1991; Shiels and González, 2014) utilizing the following methods. All non-palm trees $\geqslant 15 \mathrm{~cm}$ diameter at $1.3 \mathrm{~m}$ height (d.b.h.) within the $30 \times 30 \mathrm{~m}$ plot had branches that were less than $10 \mathrm{~cm}$ diameter removed. For non-palm trees between 10 and $15 \mathrm{~cm}$ d.b.h., each tree was trimmed at $3 \mathrm{~m}$ height. For palms $\geqslant 3 \mathrm{~m}$ tall (at the highest part of the leaf above ground), all leaves were trimmed at the connection with the main stem, and the apical meristem was preserved. Therefore, except for some palms that had leaves attached to their stem below $3 \mathrm{~m}$ height, no vegetation of any type was trimmed below $3 \mathrm{~m}$ height. Debris $\left(5408 \pm 143 \mathrm{~kg}\right.$ dry-mass per plot, or $\left.6 \mathrm{~kg} \mathrm{~m}^{-2}\right)$ was added into the Trim + debris and No trim + debris plots by spreading it evenly across each plot. The amount of debris added to our plots were similar to that naturally deposited in this forest during Hurricane Hugo; although the treatments in our study area resulted in slightly higher wood biomass and a litter layer that was $1.5 \mathrm{~cm}$ deeper (Shiels et al., 2010). Understory light (percent canopy openness) at $1 \mathrm{~m}$ height and the percent cover of the woody debris throughout the study are reported in Shiels et al. (2010) and updated in Shiels and González (2014).

\subsection{Fern monitoring and measuring}

To minimize edge effects associated with the treatments, a central $20 \times 20 \mathrm{~m}$ interior monitoring area was delineated within each $30 \times 30 \mathrm{~m}$ treatment plot. Additionally, the $20 \times 20 \mathrm{~m}$ interior plot area was divided into a grid of 16 quadrats (each c. $4.7 \times 4.7 \mathrm{~m}$ ) with walking trails ( $0.4 \mathrm{~m}$ wide) established between adjacent quadrats to minimize disturbance. Thus, the effective fern census area (whole plots surveys) for each of the $20 \times 20 \mathrm{~m}$ interior plot area was $353 \mathrm{~m}^{2}$ within which we counted and identified ferns that were rooted in the soil and had leaves $>10 \mathrm{~cm}$ in length. We conducted these whole plot surveys annually in January to assess changes in species abundance and richness. There were two pre-treatment whole plot surveys (2002-2003) and five post-treatment whole plot surveys (2005-2009). We did not conduct an annual survey of the whole plots for 2004 because it would have occurred in January 2005 during the plot treatment period which lasted from November 2004 through June 2005.

In addition, we annually monitored and measured a subsample of individual ferns in five plant subplots $(1.0 \times 3.5 \mathrm{~m})$ within a whole plot. Each plant subplot was randomly located in one of the subset of the plot's 16 quadrats that had <25\% exposed rock. During surveys of the 60 plant subplots, each individual fern with leaves $>10 \mathrm{~cm}$ in length was identified, tagged, and measured for the length of the longest leaf and whether or not it had spores, and number of leaves per individual. Changes in plant size (growth) were evaluated annually based on leaf count and leaf length for each tagged plant. Each plant subplot survey from 2003 through 2009 was conducted in the latter half of the year (avoiding the plot treatment period from November 2004 through June 2005) and individual plant mortality was also noted.

\subsection{Resistance and resilience}

Fern resistance and resilience to the canopy opening and debris deposition were assessed for the two most common ferns based on the extent to which each response variable (abundance, leaf count, leaf length and spore production) deviated from pre-treatment values. The amplitude and duration of change were used to classify each response within the five post-treatment years. To allow comparison of our resulting resistance and resilience values to the organismal and process responses to Hurricane Hugo reported in Zimmerman et al. (1996), we used the same 15\% threshold that they had found appropriate based on the magnitude of responses they observed. Thus resistance implies that there was no change in the response that exceeded $15 \%$ above or below the pre-treatment value, while resilience implies that there was change that exceeded $15 \%$ above or below pre-treatment levels, but that the difference was less than $15 \%$ by the end of the study. To reflect the absence of any experimental disturbance in the No trim + no debris treatment the term "stability" is used in place of "resistance".

\subsection{Data analysis}

Data for the whole plot surveys are available to the public on the Luquillo LTER website at <http://luq.lternet.edu/data/luqmetadata146> and for the plant subplot surveys at <http://luq.lternet. edu/data/luqmetadata143>. Repeated-measures two-way ANOVAs (Analytical Software, 2013) were used to test for changes in responses to treatments over time for all fern species combined and for the two most common fern species. Dependent variables were abundance, recruitment, mortality, leaf length, leaf count (per individual) and percentage of plants with spore-bearing leaves. The values in each of the five plant subplots in each treatment plot were averaged prior to analysis to ensure replication was sustained at the plot level ( $n=3$ per treatment). Fixed effects were the manipulations performed (trimming and debris additions) and blocks were the random effects. Significance assessments were based on $p<0.05$.

\section{Results}

\subsection{Species richness}

Sixteen species of terrestrial ferns were identified in the whole plot surveys conducted during the experiment (Table 1). Twelve 
Table 1

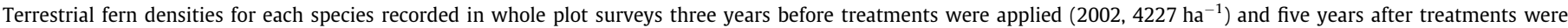

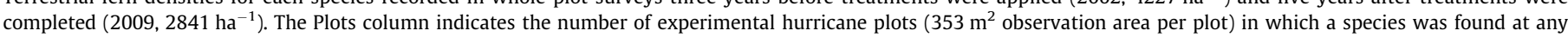

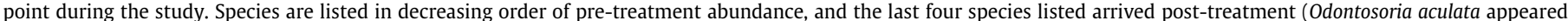

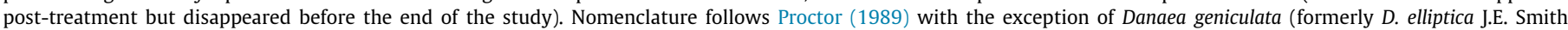

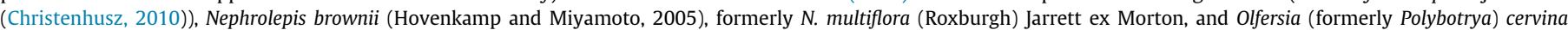
(Linnaeus) Kaulfuss (Mickel and Smith, 2004).

\begin{tabular}{|c|c|c|c|c|}
\hline \multirow[t]{2}{*}{ Plots } & \multicolumn{2}{|c|}{ Density $\left(\mathrm{ha}^{-1}\right)$} & \multirow[t]{2}{*}{ Code } & \multirow[t]{2}{*}{ Species name } \\
\hline & 2002 & 2009 & & \\
\hline 12 & 2558 & 1521 & THEDEL & Thelypteris deltoidea (Sw.) Proctor \\
\hline 11 & 912 & 731 & CYABOR & Cyathea borinquena (Maxon) Domin \\
\hline 5 & 205 & 231 & DANGEN & Danaea geniculata Raddi \\
\hline 6 & 196 & 73 & NEPRIV & Nephrolepis rivularis (Vahl) C. Christensen \\
\hline 2 & 191 & 149 & ADIPET & Adiantum petiolatum Desvaux \\
\hline 2 & 75 & 21 & BLEOCC & Blechnum occidentale L. \\
\hline 5 & 64 & 28 & LINLAN & Lindsaea lancea (Linneaus) Beddome \\
\hline 2 & 7 & 9 & LINQUA & Lindsaea quadrangularis Raddi ssp. antillensis Kramer \\
\hline 1 & 7 & 7 & CYAHOR & Cyathea horrida (Linnaeus) J.E. Smith \\
\hline 3 & 7 & 2 & ELARIG & Elaphoglossum rigidum (Aublet) Urban \\
\hline 1 & 2 & 2 & CYAPOR & Cyathea portoricensis Sprengel ex Kuhn \\
\hline 1 & 2 & 0 & OLFCER & Olfersia cervina (L.) Kunze \\
\hline 4 & 0 & 33 & CYAARB & Cyathea arborea (Linnaeus) J.E. Smith \\
\hline 1 & 0 & 31 & NEPBRO & Nephrolepis brownii (Desv.) Hovenkamp \& Miyam \\
\hline 1 & 0 & 0 & ODOACU & Odontosoria aculeata (L.) J. Smith \\
\hline 1 & 0 & 2 & ODOSCA & Odontosoria scandens (Desvaux) Christensen \\
\hline
\end{tabular}

species were present in 2002 before the treatments were applied and 14 were present at the end of the study in 2009. Four species appeared after the treatments, but only three of them were still present at the end of the study. Juveniles of $C$. arborea, a tree fern commonly found in open areas of the LEF, appeared in 2005 immediately after open canopy treatments were applied (Fig. 1); C. arborea eventually inhabited four open canopy plots (14 individuals). In 2005 (post-treatment) Nephrolepis brownii, an Asian fern species common in disturbed areas, spread by runners within a single Trim + debris plot (13 plants) that was located closer than any of the other plots to a well-established $N$. brownii population along a roadside (see plot map in Richardson et al., 2010). Two individuals of the climbing fern Odontosoria scandens also appeared after treatment, one in a Trim + no debris plot (2005) and one in a Trim + debris plot (2008), but the plant in the latter plot had disappeared by 2009. Odontosoria aculeata, a thorny climbing fern, made only a fleeting appearance in $2005(n=1)$ in one Trim + no debris plot, and again $(n=3)$ in another location within the same plot in 2006 but 0 . aculeata was absent by 2009 . Many of the fern species were absent from several of the plots (Table 1, Fig. 1) and only Thelypteris deltoidea and Cyathea borinquena (a non-arborescent member of a tree fern genus) were present throughout the experiment in all four treatments (Fig. 1).

Fern species richness varied among plots even before treatments were applied (Fig. 1), ranging from five species in the plots later assigned to the No trim + no debris treatment to nine species in the plots assigned to the No trim + debris treatment. Five years after treatment application, species counts ranged from four species in the No trim + no debris plots to nine species in the Trim + debris plots, with decreases in the No trim plots (Fig. 1b and d), and increases following the two Trim treatments (Fig. 1f and $\mathrm{h})$.

\subsection{Abundance, recruitment and mortality}

Abundance was not evenly distributed among fern species and there was a 33\% reduction in overall fern density between 2002 and 2009 (Table 1). There were few changes in species dominance during our study (Fig. 1). Two species (T. deltoidea and C. borinquena) dominated the fern community; they accounted for $82 \%$ of the pre-treatment fern density, and constituted $79 \%$ of the post-treatment fern abundance. Among the 14 less common species noted during the whole plot surveys (Table 1), only four did not decrease in abundance: Cyathea horrida (no change), Cyathea portericensis (no change), Danaea geniculata (13\% increase) and Lindsaea quadrangularis (33\% increase).

Fern abundance in the No trim + no debris treatment plots was only about half that of other plots even before treatments were initiated (Fig. 2a). There was a significant decline in fern abundance during our study directly after treatments were applied (time, $F_{6,48}=14.69, p<0.0001$ ) but then there was a gradual increase in fern abundance for the final four years in response to the Trim treatments (time $\times$ trim, $F_{6,48}=6.89, p<0.0001$; Fig. 2a). There was no subsequent change in abundance over time in the debris treatments (time $\times$ debris, $F_{6,48}=0.89, p=0.5102$; Fig. 2a). There was a significant interaction (time $\times$ trim $\times$ debris) due to the reduction in abundance in the No trim + debris treatment from pre- to post-treatment $\left(F_{6,48}=5.17, p=0.0004\right.$; Fig. $\left.2 \mathrm{a}\right)$. The annual fluctuations and treatment responses of total fern species abundance (Fig. 2a) in part reflected the response of the very common T. deltoidea, which also significantly declined (40\%) in abundance during the study (time, $F_{6,48}=15.56, p<0.0001$; Fig. $2 b$ ). $T$. deltoidea abundance in trim plots was significantly greater than closed canopy plots following treatment application (time $\times$ trim, $F_{6,48}=3.00, p=0.0144$; Fig. $2 \mathrm{~b}$ ). Similar to the response of the entire fern community, there was a significant interaction (time $\times$ trim $\times$ debris) for $T$. deltoidea due to the reduction in abundance in the No trim + debris treatment from pre- to posttreatment $\left(F_{6,48}=3.15, p=0.0110\right.$; Fig. $\left.2 b\right)$. Changes in abundance of $C$. borinquena through time were much smaller (20\%) than for T. deltoidea but followed the same pattern (time $\times$ trim, $F_{6,48}=2.63, p=0.0277$; Fig. $2 c$ ). C. borinquena abundance had a small but non-significant decline in the No trim + debris treatment, and changed little (all treatments averaged) over time $\left(F_{6,48}=1.10\right.$, $p=0.3784$; Fig. 2c). There were no additional significant differences in fern abundance involving the independent or interactive effects that were measured.

Recruitment levels for ferns (individuals achieving $>10 \mathrm{~cm}$ height during the study) were low throughout the experiment with most new individuals tending to appear in the trimmed plots but there were no significant differences in recruitment $(p>0.05$; Fig. 3a). There was a significant increase (all treatments averaged) in mortality from pre- to post-treatment (time, $F_{5,40}=5.04$, $p=0.0011$, yet this difference was largely due to the significant 

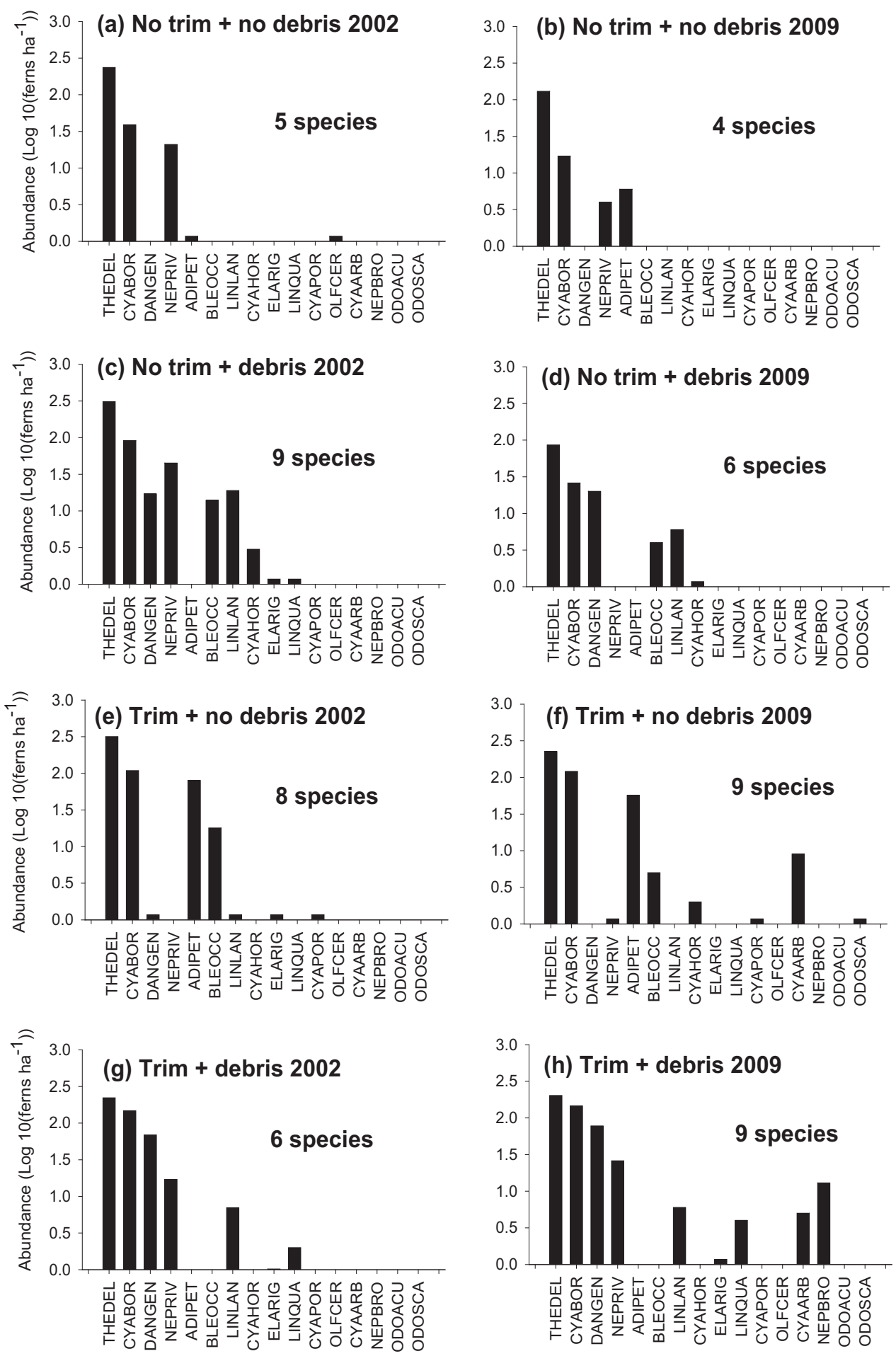

SPECIES

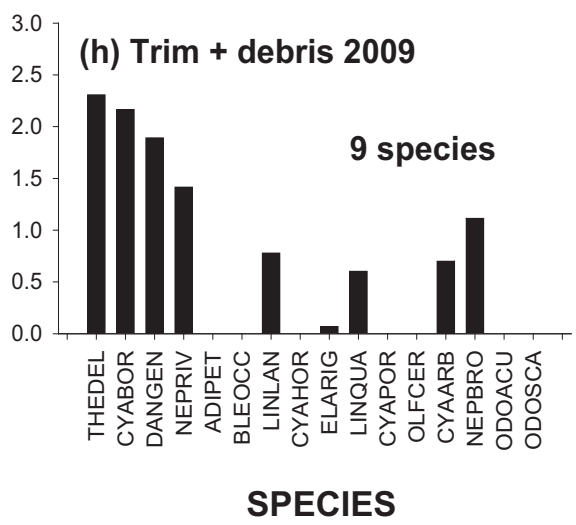

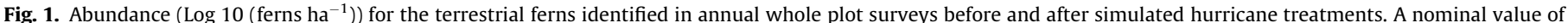

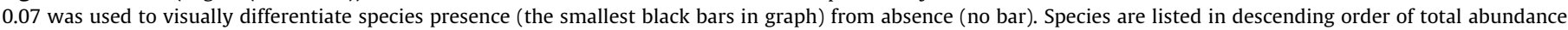
during pre-treatment conditions. See Table 1 for codes for fern species names used on the horizontal axis.

increase in mortality in the debris plots following treatment applications (time $\times$ debris, $F_{5,40}=2.95, p=0.0234$; Fig. $3 \mathrm{~b}$ ). There were no additional significant differences in fern mortality.

\subsection{Growth and spore production}

Only individuals of the two most common fern species, $T$. deltoidea $(n=43)$ and $C$. borinquena $(n=11)$, were present in the plant subplots for all 7 years of monitoring (2003-2009). Except in the No trim + no debris treatment, we found that leaves produced by T. deltoidea immediately after treatment tended to be shorter than those measured during pre-treatment surveys (Fig. 4a). However, there was a significant increase in leaf length in those leaf cohorts that emerged during the next three years in response to the two trim treatments (trim $\times$ time, $F_{6,42}=3.74, p=0.0045$; Fig. 4a). 

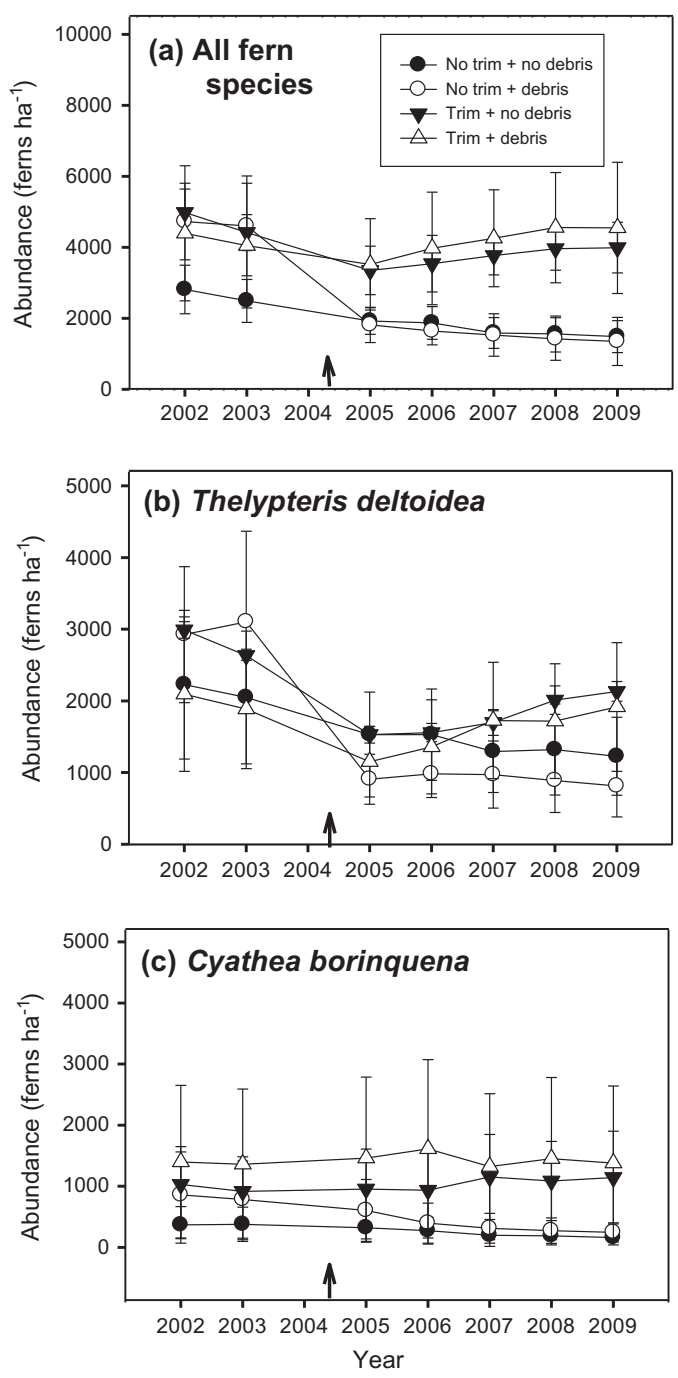

Fig. 2. Annual mean ( \pm SE) abundance of ferns (ferns ha ${ }^{-1}$ ) from whole plot surveys for four treatments for all fern species (a), and for the two most common species Thelypteris deltoidea (b), and Cyathea borinquena (c). There was no census data for 2004 because treatments were in progress. Treatment completion dates are marked by an arrow and were completed prior to the 2005 observations.

T. deltoidea leaf lengths tended to decline toward pre-trim levels in 2009 for the Trim + no debris treatment. There was a significant interaction (time $\times$ trim $\times$ debris) due to the reduction in leaf length in the No trim + debris treatment from pre- to posttreatment $\left(F_{6,42}=2.67, p=0.0274\right.$; Fig $\left.4 \mathrm{a}\right)$. There were no individuals of $C$. borinquena in the No trim + no debris plant subplots during the study; the No trim + debris plant subplots only had six individuals in 2003, none of which survived all seven years of the experiment. Therefore, statistical analysis of growth factors (leaf count, leaf length and spore production) for $C$. borinquena for No trim treatments was not possible (Fig. $4 \mathrm{~b}, \mathrm{~d}, \mathrm{f}$ ). However, for those C. borinquena plants in the trim treatments, leaf lengths tended to increase during the two years after treatments were applied and then declined to pre-treatment levels for Trim + debris and well below pre-treatment levels for Trim + no debris by the last year of the experiment (Fig. 4b).

The number of leaves per $T$. deltoidea individual was stable prior to treatments, but had increased by the end of the experiment (time, $F_{6,24}=2.88, p=0.0292$; Fig. $4 \mathrm{c}$ ). Per plant leaf counts doubled in Trim + debris and tripled in Trim + no debris treatments within two years post-treatment and the number of leaves was significantly greater in trim plots than in closed canopy plots
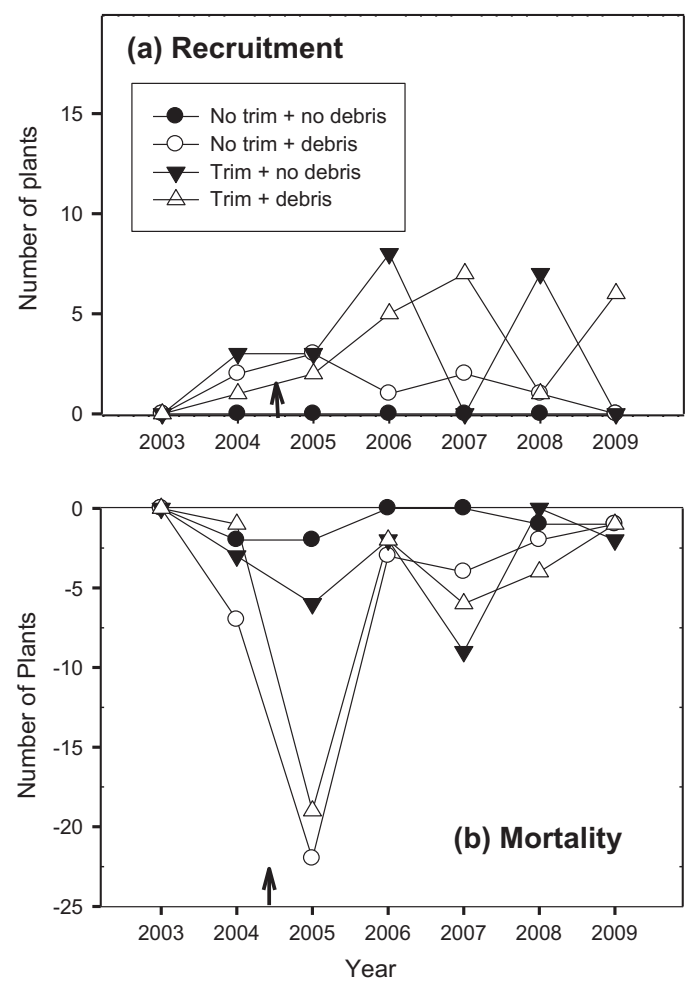

Fig. 3. Recruitment (a) and mortality (b) for all ferns in plant subplots relative to our initial observations in 2003. Treatment completion dates are marked by an arrow and were completed prior to the 2005 observations.

(trim $\times$ time, $F_{6,24}=5.70, p=0.0008$; Fig. $4 \mathrm{c}$ ). There was also a temporary $50 \%$ reduction in the number of leaves in No trim + debris plots in 2005. The leaf counts for $T$. deltoidea in trim plots had not returned to pre-treatment levels by the end of the experiment (Fig. 4c). For $C$. borinquena there was a three-fold increase in the number of leaves per plant within three years of trimming compared to pre-treatment measures, although by 2009 the number of leaves had returned to near pre-treatment levels (Fig. 4d).

There was a significantly higher percentage of spore-bearing $T$. deltoidea leaves on plants in trim plots than in non-trim plots (trim, $F_{1,5}=16.64, p=0.0095$ ), and the percentage of individuals producing spores returned to near or below pre-treatment (2004) levels by 2009 (Fig. 4e). T. deltoidea pre-treatment spore production in the No trim + no debris plots averaged $10-20 \%$, then decreased to nearly zero spore production three years posttreatment before returning to $10-20 \%$ in the final two years (Fig. 4e). There was no post-treatment spore production by T. deltoidea in the No trim + debris plots immediately prior to treatment and in the post-treatment years (Fig. 4e). C. borinquena exhibited an immediate increase in spore production in direct response to trimming (Fig. $4 \mathrm{f}$ ), and then tended to decline slowly (Trim + debris) or rapidly (Trim + no debris).

\subsection{Resistance and resilience}

Species richness was resistant to No debris treatments (Fig. 1a, b, e, f) but decreased 33\% in response to the No trim + debris treatment (Fig. 1c and d) and increased 33\% in response to the Trim + debris treatment (Fig. $1 \mathrm{~g}$ and $\mathrm{h}$ ); species composition also changed. $T$. deltoidea and $C$. borinquena demonstrated a variety of responses in abundance, growth and spore production (Table 2). The majority of responses for both species were either increases (maximum amplitude: $+1400 \%$ spore production by $T$. deltoidea in response to Trim + debris) or decreases (maximum amplitude: $-100 \%$ spore 

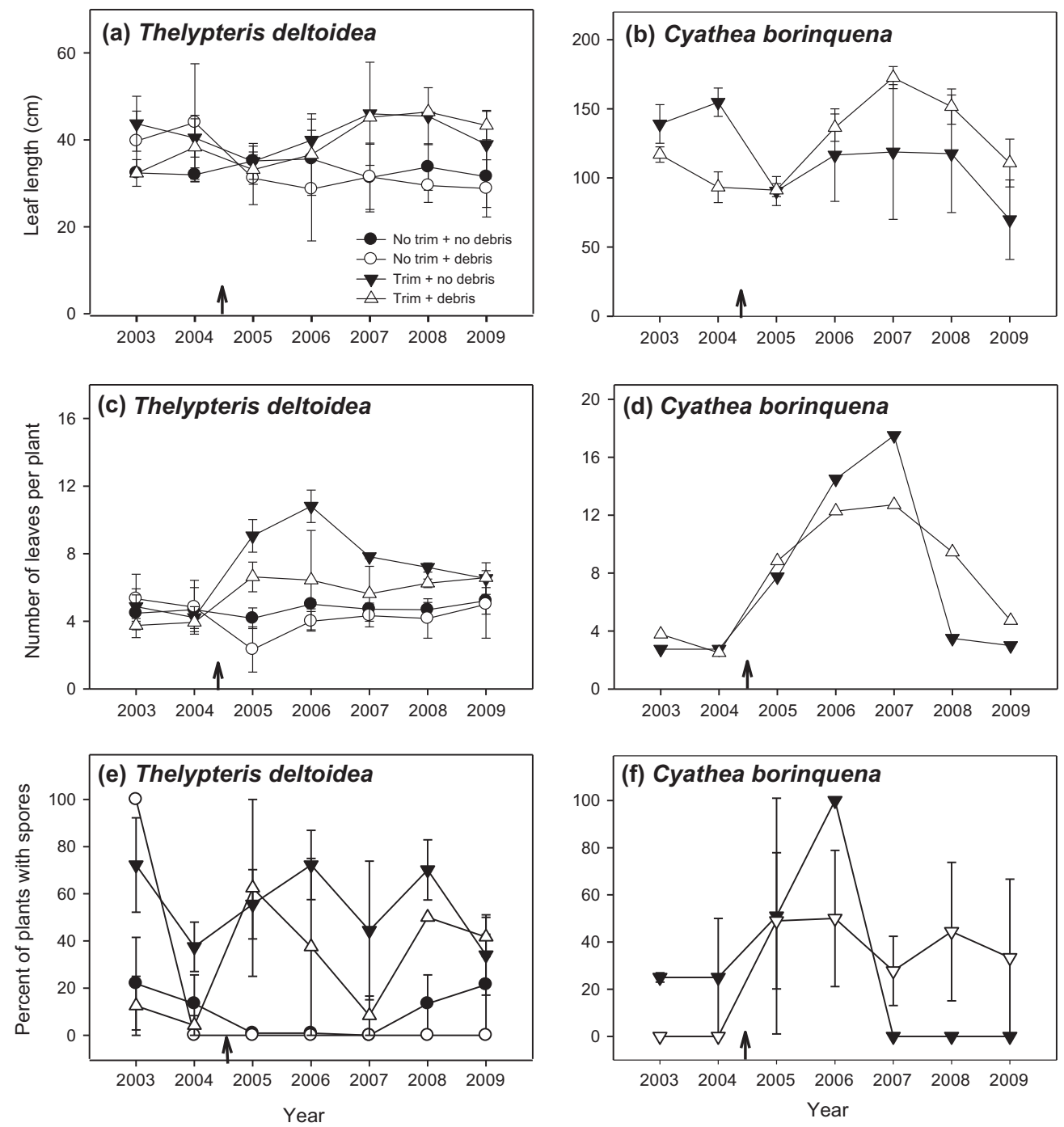

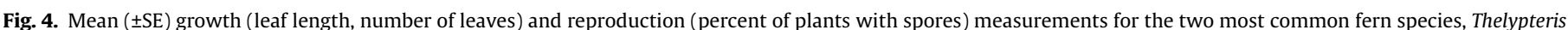

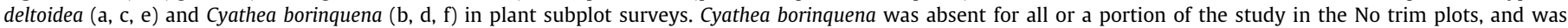

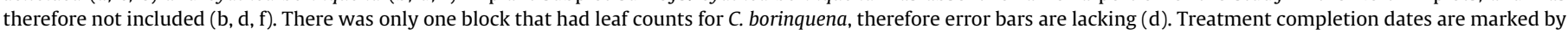
an arrow and were completed prior to the 2005 observations.

production in response to Trim + no debris for C. borinquena) and these were trends that had not abated within the five post-treatment years of the study (Table 2). For $T$. deltoidea, the response of leaf length was resistant to Trim + no debris while leaf length and leaf count remained stable in response to No trim + no debris. Resilience times of three years were evident in abundance for both species, and for leaf count in response to No trim + debris for T. deltoidea. A resilience time of four years characterized the response of spore production to Trim + no debris for $T$. deltoidea and five years for leaf count to Trim + no debris for $C$. borinquena (Table 2). Resilience time was also five years for the lengths of newly emerging leaves to return to pre-treatment levels in response to Trim + debris. The amplitude of percent difference for resilient responses (Table 2 ) ranged from $+536 \%$ ( $C$. borinquena leaf count to Trim + no debris) to $-52 \%$ ( $T$. deltoidea leaf count to No trim + debris).

\section{Discussion}

Most studies of responses of plants to forest ecosystem disturbance have focused on woody plants while often neglecting the role and responses of prominent understory herbaceous plants, such as ferns (Walker and Sharpe, 2010). Our experimental hurricane treatments resulted in changes to the understory fern community that were both dramatic and species-specific, including changes in abundance, growth (leaf length, leaf count) and spore production. Removing much of the tree canopy above $3 \mathrm{~m}$ resulted in a partial shift in the functional forest canopy down to the level of the herbaceous layer (Willig et al., 2012) where ferns, graminoids, forbs and woody seedlings reside. Such a shift can also affect the structure and function of the understory organisms (Shiels et al., 2010; Richardson et al., 2010), as well as the ecosystem processes that occur in the litter layer and soil substrate below the fern canopy.

\subsection{Community structure}

The pre-treatment terrestrial fern community of the study area was typical of the vegetation of ridges and upper slopes of other experimental areas of the LEF (Smith, 1970; Halleck et al., 2004). Studies of ferns in the LEF with more comprehensive sampling protocols have shown that when lower slopes and riparian areas are included, $T$. deltoidea and $C$. borinquena are always common, yet the abundance of riparian and lower slope species such as Danaea 
Table 2

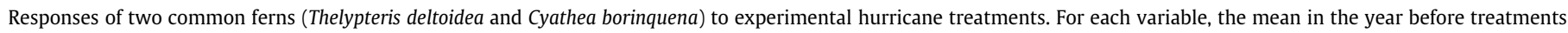

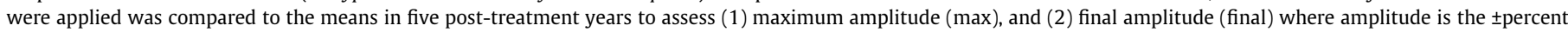

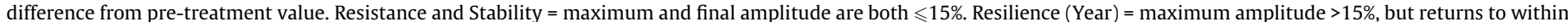

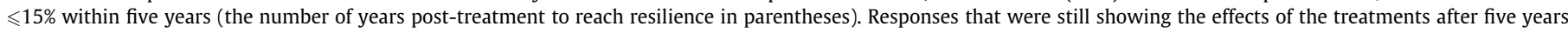

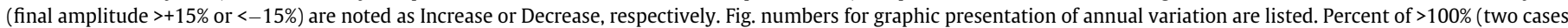

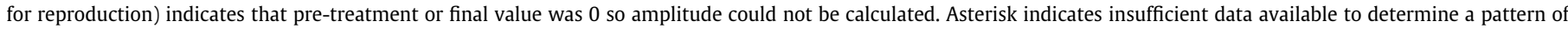
response.

\begin{tabular}{|c|c|c|c|c|c|}
\hline & \multicolumn{2}{|c|}{ Closed canopy (No trim) } & \multicolumn{2}{|c|}{ Open canopy (Trim) } & \multirow[t]{2}{*}{ Fig. } \\
\hline & $\begin{array}{l}\text { No debris } \\
\text { Response } \\
\text { Max, final (yr) }\end{array}$ & $\begin{array}{l}\text { Debris } \\
\text { Response } \\
\text { Max, final (yr) }\end{array}$ & $\begin{array}{l}\text { No debris } \\
\text { Response } \\
\text { Max, final (yr) }\end{array}$ & $\begin{array}{l}\text { Debris } \\
\text { Response } \\
\text { Max, final (yr) }\end{array}$ & \\
\hline \multicolumn{6}{|l|}{ ABUNDANCE } \\
\hline T. deltoidea & $\begin{array}{l}\text { Decrease } \\
-40 \%,-40 \%\end{array}$ & $\begin{array}{l}\text { Decrease } \\
-74 \%,-74 \%\end{array}$ & $\begin{array}{l}\text { Decrease } \\
-42 \%,-19 \%\end{array}$ & $\begin{array}{l}\text { Resilience (3) } \\
-39 \%,+2 \%\end{array}$ & $2 \mathrm{~b}$ \\
\hline C. borinquena & $\begin{array}{l}\text { Decrease } \\
-57 \%,-57 \%\end{array}$ & $\begin{array}{l}\text { Decrease } \\
-69 \%,-69 \%\end{array}$ & $\begin{array}{l}\text { Increase } \\
+25 \%,+25 \%\end{array}$ & $\begin{array}{l}\text { Resilience (3) } \\
+19 \%,+1 \%\end{array}$ & $2 c$ \\
\hline \multicolumn{6}{|l|}{ GROWTH } \\
\hline T. deltoidea & $\begin{array}{l}\text { Stability } \\
+11 \%,-1 \%\end{array}$ & $\begin{array}{l}\text { Decrease } \\
-35 \%,-34 \%\end{array}$ & $\begin{array}{l}\text { Resistance } \\
+14 \%,-4 \%\end{array}$ & $\begin{array}{l}\text { Resilience (5) } \\
+21 \%,+13 \%\end{array}$ & $4 a$ \\
\hline C. borinquena & * & $*$ & $\begin{array}{l}\text { Decrease } \\
-55 \%,-55 \%\end{array}$ & $\begin{array}{l}\text { Increase } \\
+85 \%,+19 \%\end{array}$ & $4 a$ \\
\hline \multicolumn{6}{|l|}{ Leaf count } \\
\hline T. deltoidea & $\begin{array}{l}\text { Stability } \\
-11 \%,+11 \%\end{array}$ & $\begin{array}{l}\text { Resilience (3) } \\
-52 \%,+3 \%\end{array}$ & $\begin{array}{l}\text { Increase } \\
+156 \%,+55 \%\end{array}$ & $\begin{array}{l}\text { Increase } \\
+68 \%,+67 \%\end{array}$ & $4 b$ \\
\hline C. borinquena & * & * & $\begin{array}{l}\text { Resilience (5) } \\
+536 \%,+9 \%\end{array}$ & $\begin{array}{l}\text { Increase } \\
+409 \%,+89 \%\end{array}$ & $4 \mathrm{~b}$ \\
\hline \multicolumn{6}{|l|}{ REPRODUCTION } \\
\hline T. deltoidea & $\begin{array}{l}\text { Increase } \\
-100 \%, 60 \%\end{array}$ & $\begin{array}{l}\text { Decrease } \\
>100 \%,>100 \%\end{array}$ & $\begin{array}{l}\text { Resilience (4) } \\
93 \%,-9 \%\end{array}$ & $\begin{array}{l}\text { Increase } \\
1400 \%, 900 \%\end{array}$ & $4 \mathrm{c}$ \\
\hline C. borinquena & * & $*$ & $\begin{array}{l}\text { Decrease } \\
+300 \%,-100 \%\end{array}$ & $\begin{array}{l}\text { Increase } \\
>100 \%,>100 \%\end{array}$ & $4 c$ \\
\hline
\end{tabular}

nodosa (Royo et al., 2011) and Blechnum occidentale (Portugal Loayza, 2005) may be greater, perhaps because of increased germination on slopes with areas of bare soil exposed or due to legacies of past land uses. Ferns in this experiment experienced little change in the overall number of species over time, a finding common to observational studies of understory fern communities following wind disturbance (Chinea, 1999; Ilisson et al., 2006; Weaver, 2008), but unusual when compared to understory woody plant responses to hurricane disturbance (Guzmán-Grajales and Walker, 1991; Scatena et al., 1996; Murphy et al., 2008; Heartsill Scalley et al., 2010). Specifically, fern species compositional changes were different from woody plant responses of our hurricane experiment (Shiels et al., 2010) and other tropical hurricane studies (Walker et al., 1996; Murphy et al., 2008; Comita et al., 2009) in that for ferns (1) no resident species were lost under simulated hurricane conditions (open canopy with debris deposition), and (2) resident species instead of pioneer species continued to dominate the understory during the five years following disturbance. Two of the pioneer fern species that appeared when the canopy was opened (C. arborea and N. brownii) are prolific and commonly occur along roadsides in the LEF (Proctor, 1989; Walker et al., 2010). Mature individuals of the tree fern C. arborea in the LEF have been estimated to produce nearly half a trillion spores annually (Conant, 1976) and the spores can germinate in openings on bare soil, such as in landslides, river gulches, and roadsides but generally do not survive in forests with $<40 \%$ open canopy (Portugal Loayza, 2005). Once established, $C$. arborea can dominate for many years and change the trajectories of succession in LEF plant communities (Walker et al., 2010). The small number of $C$. arborea recruited in our experiment is unlike the response of the early successional native fern $D$. punctilobula that doubled in cover and dominated the understory following a temperate forest manipulation that simulated post-hurricane conditions (Cooper-Ellis et al., 1999). Establishment of pit and mound topography created by pulling trees down in the study by Cooper-Ellis et al. (1999) may have been conducive to the germination of fern spores, whereas the lack of substantial spread of $C$. arborea and other pioneer ferns in our study may have been restricted by the lack of pit and mound topography in the LEF $(<0.1 \%$ of the ground surface; Lenart et al., 2010) and the very few patches of exposed soil in the study area. Such lack of exposed soil from infrequent windthrow is one key difference resulting from severe wind disturbances affecting the LEF relative to those affecting temperate forests (e.g. contrast Brokaw and Grear, 1991 to Fischer et al., 2013). After major hurricanes in the LEF, most trees are damaged by defoliation and branch and stem loss above $3 \mathrm{~m}$ height, and few trees are uprooted (Brokaw and Grear, 1991); these patterns recorded following natural hurricanes in the LEF guided the methodology used in our experimental treatments. The establishment of invasive $N$. brownii and its rapid spread by runners (Proctor, 1989) under open canopy highlights one of the potential risks of partial canopy loss (also see Bellingham et al., 2005; Murphy et al., 2008), and the presence and spread of $N$. brownii and other non-native invasive ferns should be carefully monitored to avoid the sort of drastic ecosystem changes caused by some non-native ferns (e.g. Lygodium microphyllum in Florida) that may flourish following hurricanes (Lynch et al., 2011).

\subsection{Fern mortality}

Changes in fern abundances reflected steady to increasing recruitment and mortality except for the rapid doubling of mortality levels in plots immediately after debris was deposited. A similar pattern of a one-year spike of mortality for both debris addition treatments was also observed for the woody seedlings in this same experiment (Shiels et al., 2010) as well as in tree densities in natural and plantation forests after Hurricane Hugo (Fu et al., 1996). A depression in fern abundance (biomass) also occurred in the LEF immediately after Hurricane Hugo (Scatena et al., 1993). In our study the magnitude of change in abundance due to mortality in response to debris deposition was greater for $T$. deltoidea than 
for $C$. borinquena, perhaps because the much larger $C$. borinquena individuals could more easily resist or recover from debris damage. C. borinquena has leaves that are approximately three times the length of $T$. deltoidea (Fig. 4a, b), and the leaves of $C$. borinquena connect to a larger rhizome at a greater height above the substrate than T. deltoidea; thus, $C$. borinquena individuals were less likely to be buried by the debris deposition treatments than the smaller $T$. deltoidea plants.

The response to physical deposition of debris in our experiment shows that hurricane debris can kill existing ferns of the forest understory; however, mortality may be slightly overstated in this experiment. Debris treatments did not actually duplicate the size distribution and patchiness of the woody debris-fall of a hurricane (Shiels et al., 2010). Unlike the short sections of wood deposited in our debris treatments, fallen branches resulting from hurricane winds have fewer contact points with the ground and the vulnerable apical meristems of ferns. Ferns in the understory of wet tropical forests are naturally subject to branch and leaf fall throughout their lives (Drake and Pratt, 2001). Long-term studies in the LEF prior to and following Hurricane Georges have revealed infrequent terrestrial fern mortality: just three of 96 monitored individuals of T. deltoidea, and none of the 57 monitored individuals of $C$. borinquena died in the years after Hurricane Georges (Sharpe, unpublished data). However, the paucity of published studies that have examined mortality rates of individual ferns and fern species after hurricanes makes it difficult to draw more than tentative conclusions about the level of physical damage resulting from experimental debris deposition.

Fern monitoring in our study has also allowed us to evaluate the negative impacts of researchers, mainly via trampling, on plot measurements. The use of ferns rather than other plant residents of the forest understory is particularly appropriate because fern species can comprise more than half of the perennial herbaceous layer community (excluding woody seedlings) of the LEF (Smith, 1970; Royo et al., 2011). Both Halleck et al. (2004) and Hill and Pickering (2009) found that ferns have low resistance to trampling, and Halleck et al. (2004) estimated that damage and mortality from incidental trampling by researchers in another large scale experiment in the LEF resulted in up to a 50\% reduction of fern abundance over a six-year period. However, in our experiment where plant subplots were small and well-marked and entry was avoided, declines in fern abundance were similar to patterns observed for whole plots. Therefore it appears that the researcher walkway system established in the plots for this experiment successfully limited this type of damage to understory ferns.

\subsection{Effect of increased light levels on spore production}

As long-term residents of the herbaceous layer of the rainforest, terrestrial ferns are accustomed to light levels that in many rainforests can be one to two percent of that reaching the canopy with increases to as much as $40 \%$ following a large hurricane (Scatena et al., 2012). In our experiment, understory light levels doubled where the canopy was opened but returned to pre-disturbance levels within 18 months (Shiels et al., 2010), which is a similar period (14-28 months) for understory light levels to recover from the effects of natural hurricanes in Caribbean forests (Fernández and Fetcher, 1991; Bellingham et al., 1995; Comita et al., 2009). Spore production has been previously linked to light availability (Steeves, 1959) and carbohydrate levels (Harvey and Caponetti, 1972) in laboratory experiments. Our field experiment results indicate that spore production can dramatically increase when light levels increase, and that added debris inputs may have a positive effect, but only in combination with added light. Greenhouse experiments have also shown that increased light (and perhaps the concomitant increase in temperature) not only increases spore production, but also growth rates and leaf lengths (Siman and Sheffield, 2002). In our study, open canopy conditions resulted in an increase in the proportion of spore-producing plants as well as longer leaves that may produce more spores. We also observed an increase in the numbers of leaves per plant in open canopy treatments, which is another indication of increased production of spore-bearing leaves (Sharpe, 2005). In a Mexican rainforest, tree ferns in high-light forest edges produced more leaves than in adjacent understory habitat where light levels were nine times lower (Bernabe et al., 1999). Flinn (2007) also found that adult ferns were more likely to be larger and produce more spores in secondary forests that had developed on agricultural lands than in undisturbed forests. PérezGarcía et al. (2007) determined that tropical spore germination was correlated with light intensity and that increased recruitment seemed to require canopy opening. Relatively high densities of the temperate understory fern Thelypteris phegopteris appeared in the most damaged and open areas of forests prone to windthrow in Estonia (Ilisson et al., 2006). Thus, increased understory light resulting from canopy disturbance appears to have a positive influence on fern reproduction, and that may partly explain the approximate $200 \%$ increase in fern abundance for $T$. deltoidea (Royo et al., 2011) and C. borinquena (Royo, unpublished data) after Hurricane Hugo that was sustained in the LEF for at least 20 years thereafter.

\subsection{How resistant or resilient are ferns to hurricane disturbance?}

Evaluations of ecosystem responses to disturbance must include the combined and interacting responses of the myriad elements of that ecosystem (Zimmerman et al., 1996; Watson and Estes, 2011). Our experiment allowed us to use concepts of resistance and resilience (Carpenter et al., 2001; Lugo et al., 2002) to interpret the responses of the understory fern community to selected elements of hurricane impacts. Ferns are common within their forest floor habitat and as perennials they are long-lived (Harper and White, 1974) and yet some variables showed evidence of resistance or resilience within the five years after experimental disturbance. Patterns of continuing increase or decrease relative to pre-treatment levels were more commonly observed however, and could represent long term phase shifts (Watson and Estes, 2011) or a much slower return to pre-treatment values (i.e. $>5$ years) such that long-lived ferns may eventually demonstrate resilience within the average 60 -year interval between severe hurricanes in the LEF. Assessment of resistance and resilience to forest floor vegetation disturbance by measuring changes in plant functional traits is a relatively recent phenomenon (e.g. BernhardtRömermann et al., 2011). The ultimate duration of increased leaf counts and spore production that were observed during the five years of the experimental hurricane treatment (open canopy with debris) may depend on the intensity, severity and extent of the disturbance (Walker, 2012). Some or all of these disturbance characteristics may have been greater when Hurricane Hugo struck another watershed of the LEF in 1989 and where fern cover continues to increase 20 years later (Royo et al., 2011). Increases in leaf area of fern individuals with funnel architecture could also result in more canopy litter being intercepted within the herbaceous layer where decomposition rates are faster than those on the forest floor (Dearden and Wardle, 2008), thus ameliorating the decomposer environment and ultimately increasing the rate of litter decomposition after a hurricane.

Stability was the expected response in unmanipulated plots, yet reductions in fern abundance occurred, which may have been due to continuing forest-wide canopy closure characterizing the longterm recovery from the most recent severe hurricane in 1998 (Comita et al., 2009). T. deltoidea exhibited resilience in abundance to canopy opening after a sharp post-treatment decline, and in leaf length (when debris was present) and spore production (when 
debris was absent) after a post-treatment increase. When our findings are compared to trajectories presented by Zimmerman et al. (1996), abundance of $T$. deltoidea showed resilience within three years after a catastrophic decline that was similar to the recovery pattern of tree biomass and density after Hurricane Hugo. Abundance of some short-lived invertebrates in this experiment also increased but then exhibited resilience (e.g. mites and Collembola, Richardson et al., 2010) but with a shorter return rate ( $<2$ years). However, abundance of the fern $C$. borinquena responded to canopy and understory disturbance by immediately resisting simulated hurricane effects and increasing in abundance before returning to pre-treatment levels, which was a pattern shared with forest floor biomass and nutrient pools after Hurricane Hugo (Zimmerman et al., 1996). Like $C$. borinquena, graminoids increased in abundance and leaf length under open canopy treatments in this experiment, but the amplitude of the increases were much greater than that of C. borinquena, and graminoids had not returned to pre-treatment levels within five years (Shiels et al., 2010). Woody seedling abundance was also less resilient than ferns to hurricane conditions in this experiment, and the woody adult plant community remained twice as abundant after 3.5 years post-treatment relative to pretreatment conditions (Shiels et al., 2010).

The understory fern community in our study has demonstrated a relatively rapid return to pre-disturbance growth rates and maintained nearly the same species composition pre- and post-disturbance. Fern resilience to hurricane impacts therefore markedly differs from the much slower return rate of tree species composition in this forest (Shiels et al., 2010). Such resilience implies that ferns will continue to be as important a component of the understory as they had been prior to disturbance, and they will also contribute a large pulse of spores to the forest soil spore bank. Although mostly resilient in this experiment, the fern community may be more vulnerable to long-term changes if again subjected to a disturbance before the spores released into the spore bank lose their viability (Ramírez-Trejo et al., 2004). Observations within the LEF of continued population increases for some understory ferns after two hurricanes (Hugo, Georges) in relatively short (9 years) succession (Royo et al., 2011) may in part reflect successful recruitment from spores. Experimental tests of fern resilience to repeated hurricane disturbance should be a priority for future research.

\section{Conclusions}

The inclusion of ferns in this large scale experiment has increased our understanding of the key factors (canopy openness, debris deposition) necessary for population and community resistance and resilience during hurricane impacts to this tropical forest. Increases in abundance, growth and reproduction over time following canopy opening treatments regardless of whether or not canopy debris was simultaneously added to the forest floor highlights the importance of light level changes at ground level as an indirect effect of canopy damage. Increased spore production and subsequent recruitment in response to canopy opening by hurricanes have the potential to change the characteristics of fern populations within the forest herbaceous layer community. Fern reproduction and expansion may further change the litter and soil communities below their canopies, particularly if hurricane interval times are reduced to within the viability limits of the spores, as suggested by Royo and Carson (2006). Long-lived ferns spend most of their lives in low light conditions, producing relatively small leaves and exhibiting slow growth rates. This experiment demonstrates that understory ferns that are not lost to canopy debris deposition do have the capability to resist and recover from hurricane-related canopy and forest floor disturbances. Ferns often dominate the forest understory community and may partly regulate plant community structure, as well as the light, litter levels, and other organisms that reside on the forest floor and in the topsoil. Drawing from our findings, future studies should focus on fern resistance and resilience thresholds, and long-term influences of ferns on community and ecosystem processes following hurricanes.

\section{Acknowledgements}

We thank those who thoughtfully planned this large scale experiment for including ferns in their long list of forest components to be measured. For those many hours spent setting up the experimental plots, we thank the many volunteers and the staff of the El Verde Station who performed that arduous work. We also appreciate the work of those who meticulously documented the growth of ferns in the plant subplots from year to year: Pedro Anglada Cordero, María Aponte, John Bithorn, Rebeca de Jesús, Ligia Lebrón, Samuel Matta, Chris Nytch, Paola Olaya and Nereida Ramírez. We acknowledge the excellent work of entering and editing the plant subplot data by John Monge and thank Eda Meléndez, the Luquillo LTER information manager, for her outstanding stewardship of the experiment's data sets. We also thank volunteers Thomas J. Bennett IV, Bella Provan, Jane McKinney Kaler and Meredith Fossel for their field assistance with the annual whole plot fern surveys, and Lawrence Walker and two anonymous reviewers for helpful comments on an earlier version of this manuscript. This research was funded by grants DEB-0218039 and DEB-0620910 from the National Science Foundation to the Institute for Tropical Forestry, USDA Forest Service, as part of the Luquillo Long-Term Ecological Research Program. Additional direct support was provided by the University of Puerto Rico and the USDA Forest Service.

\section{References}

Analytical Software Inc., 2013. Statistix 10. Analytical Software Inc., Tallahassee Florida USA.

Beard, K.H., Vogt, K.A., Vogt, D.J., Scatena, F.N., Covich, A.P., Sigurdardottir, R., Siccama, T.G., Crowl, T.A., 2005. Structural and functional responses of a subtropical forest to 10 years of hurricanes and droughts. Ecol. Monogr. 75, 345-361.

Bellingham, P.J., Tanner, E.V.J., Healey, J.R., 1995. Damage and responsiveness of Jamaican montane tree species after disturbance by a hurricane. Ecology 76, 2562-2580.

Bellingham, P.J., Tanner, E.V.J., Healey, J.R., 2005. Hurricane disturbance accelerates invasion by the alien tree Pittisporum undulatum in Jamaican montane rain forests. J. Veg. Sci. 16, 675-684.

Bernabe, N., Williams-Linera, G., Palacios-Rios, M., 1999. Tree ferns in the interior and at the edge of a Mexican cloud forest remnant: spore germination and sporophyte survival and establishment. Biotropica 31, 83-88.

Bernhardt-Römermann, M., Gray, A., Vanbergen, A.J., Bergès, L., Bohner, A., Brooker R.W., De Bruyn, L., De Cinti, B., Dirnböck, T., Grandin, U., Hester, A.J., Kanka, R., Klotz, S., Loucougaray, G., Lundin, L., Matteaucci, G., Mészáros, I., Oláh, V., Preda, E., Prévosto, B., Pykälä, J., Schmidt, W., Taylor, M.E., Vadineanu, A., Waldmann, T., Stadler, J., 2011. Functional traits and local environment predict vegetation responses to disturbance: a pan-European multi-site experiment. J. Ecol. 99, 777-787.

Brokaw, N.V.L., Grear, J.S., 1991. Forest structure before and after hurricane Hugo at three elevations in the Luquillo Mountains, Puerto Rico. Biotropica 23, 386-392.

Brokaw, N.V.L., Walker, L.R., 1991. Summary of the effects of Caribbean hurricanes on vegetation. Biotropica 23, 442-447.

Brokaw, N., Fraver, S., Grear, J.S., Thompson, J., Zimmerman, J.K., Waide, R.B., Everham III, E.M., Hubbell, S.P., Foster, R.B., 2004. Disturbance and canopy structure in two tropical forests. In: Losos, E.C., Leigh, E.G., Jr. (Eds.), Tropical Forest Diversity and Dynamism: Findings from a Large-Scale Plot Network. The University of Chicago Press, Chicago, pp. 177-194.

Burslem, D.F.R.P., Whitmore, T.C., Brown, G.C., 2000. Short-term effects of cyclone impact and long-term recovery of tropical rain forest on Kolombangara, Solomon Islands. J. Ecol. 88, 1063-1078.

Canham, C.D., Thompson, J., Zimmerman, J.K., Uriarte, M., 2010. Variation in susceptibility to hurricane damage as a function of storm intensity in Puerto Rican tree species. Biotropica 42, 87-94.

Carpenter, S.R., Walter, B., Anderies, J.M., Abel, N., 2001. From metaphor to measurement: resilience of what to what? Ecosystems 4, 765-781.

Chinea, J.D., 1999. Changes in the herbaceous and vine communities at the Bisley Experimental Watersheds, Puerto Rico, following hurricane Hugo. Can. J. For. Res. 29, 1433-1437. 
Christenhusz, M.J.M., 2010. Danaea (Marattiaceae) revisited: biodiversity, a new classification and ten new species of a neotropical fern genus. Bot. J. Linn. Soc. 163, 360-385.

Comita, L.S., Uriarte, M., Thompson, J., Jonckheere, I., Canham, C.D., Zimmerman, J.K., 2009. Abiotic and biotic drivers of seedling survival in a hurricane-impacted tropical forest. J. Ecol. 97, 1346-1359.

Conant, D., 1976. Ecogeographic and systematic studies in American Cyatheaceae. Dissertation. Harvard University, Cambridge MA, USA.

Cooper-Ellis, S., Foster, D.R., Carlton, G., Lezberg, A., 1999. Forest response to catastrophic wind: results from an experimental hurricane. Ecology 80, 26832696.

Dearden, F.M., Wardle, D.A., 2008. The potential for forest canopy litterfall interception by a dense fern understorey, and the consequences of litter decomposition. Oikos 117, 83-92.

Drake, D.R., Pratt, L.W., 2001. Seedling mortality in Hawaiian rain forest: the role of small-scale physical disturbance. Biotropica 33, 319-323.

Enrico, L., Funes, G., Cabido, M., 2004. Regeneration of Polylepis australis Bitt. in the mountains of central Argentina. For. Ecol. Manag. 190, 301-309.

Ewel, J.J., Whitmore, J.L., 1973. The ecological life zones of Puerto Rico and the U.S. Virgin Islands. Forest Service Research Report ITF18. Institute of Tropical Forestry, Rio Piedras, Puerto Rico.

Fernández, D.S., Fetcher, N., 1991. Changes in light availability following Hurricane Hugo in a subtropical montane forest in Puerto Rico. Biotropica 23, 393-399.

Fischer, A., Marshall, P., Camp, A., 2013. Disturbances in deciduous temperate forest ecosystems of the northern hemisphere: their effects on both recent and future forest development. Biodivers. Conserv. 22, 1863-1893.

Flinn, K.M., 2007. Microsite-limited recruitment controls fern colonization of postagricultural forests. Ecology 88, 3103-3114

Fu, S., Rodríguez Pedraza, C., Lugo, A.E., 1996. A twelve-year comparison of stand changes in a mahogany plantation and a paired natural forest of similar age. Biotropica 28, 515-524.

Gentry, A.H., Dodson, C., 1987. Contribution of nontrees to species richness of a tropical rain forest. Biotropica 19, 149-155.

George, L.O., Bazzaz, F.A., 2003. The herbaceous layer as a filter determining spatial pattern in forest tree regeneration. In: Gilliam, F.S., Roberts, M.R. (Eds.), The Herbaceous Layer in Forests of Eastern North America. Oxford University Press, New York, pp. 265-282.

Guzmán-Grajales, S.M., Walker, L.R., 1991. Differential seedling responses to litter after Hurricane Hugo in the Luquillo Experimental Forest, Puerto Rico. Biotropica 23, 407-413.

Halleck, L.F., Sharpe, J.M., Zou, X., 2004. Understorey fern responses to posthurricane fertilization and debris removal in a Puerto Rican rain forest. J. Trop. Ecol. 20, 173-181.

Harper, J.L., White, J., 1974. The demography of plants. Ann. Rev. Ecol. Syst. 5, 419463.

Harvey, W.H., Caponetti, J.D., 1972. In vitro studies of sporogenous tissue on leaves of cinnamon fern. I. Environmental factors. Can. J. Bot. 50, 2673-2682.

Heartsill Scalley, T., Scatena, F.N., Lugo, A.E., Moya, S., Ruiz, C.R.E., 2010. Changes in structure, composition, and nutrients during 15 years of hurricane-induced succession in a subtropical wet forest in Puerto Rico. Biotropica 42, 455-463.

Hill, R., Pickering, C., 2009. Differences in resistance of three subtropical vegetation types to experimental trampling. J. Environ. Manag. 90, 1305-1312.

Holling, C.S., 1973. Resilience and stability of ecosystems. Annu. Rev. Ecol. Syst. 4, $1-23$.

Ilisson, T., Metslaid, M., Vodde, F., Jõgiste, K., Kurm, M., 2006. Vascular plant response to windthrow severity in Norway spruce-dominated Myrtillus site type forests in Estonia. Ecoscience 13, 193-202.

Imbert, D., Portecop, J., 2008. Hurricane disturbance and forest resilience: assessing structural vs. functional changes in a Caribbean dry forest. For. Ecol. Manag. 55, 3494-3501.

Lenart, M.T., Falk, D.A., Scatena, F.N., Osterkamp, W.R., 2010. Estimating soil turnover rate from tree uprooting during hurricanes in Puerto Rico. For. Ecol. Manag. 259, 1076-1084.

Lugo, A.E., 2008. Visible and invisible effects of hurricanes on forest ecosystems: an international review. Aust. Ecol. 33, 368-398.

Lugo, A.E., Scatena, F.N., Silver, W., Molina Colón, S., Murphy, P.G., 2002. Resilience of tropical wet and dry forests in Puerto Rico. In: Gunderson, L.H., Pritchard, L. Jr. (Eds.), Resilience and Behavior of Large-scale Systems. Island Press, Washington, DC, pp. 195-225.

Lugo, A.E., Scatena, F.N., Waide, R.B., Greathouse, E.A., Pringle, C.M., Willig, M.R., Vogt, K.A., Walker, L.R., González, G., McDowell, W.H., Thompson, J., 2012. Management implications and applications of long-term ecological research. In: Brokaw, N., Crowl, T.A., Lugo, A.E., McDowell, W.H., Scatena, F.N., Waide, R.B. Willig, M.R. (Eds.), A Caribbean Forest Tapestry, the Multidimensional Nature of Disturbance and Response. Oxford University Press, Oxford, pp. 305-360.

Lynch, R.L., Brandt, L.A., Chen, H., Ogurcak, D., Fujisaki, I., Mazzotti, F.J., 2011. Recruitment and growth of Old World climbing fern in hurricane-caused canopy gaps. J. Fish Wildl. Manag. 2, 199-206.

Melendez-Ackerman, E.J., Calisto-Perez, C., Morales-Vargas, M., Fumero-Caban, J., 2003. Post-hurricane recovery of a herbaceous understorey plant in a tropical rain forest in Puerto Rico. J. Trop. Ecol. 19, 677-684.

Mickel, J.T., Smith, A.R., 2004. The pteridophytes of Mexico. Mem. New York Bot. Gard. 88, 1-1054.

Murphy, H.T., Metcalfe, D.J., Bradford, M.G., Ford, A.F., Galway, K.E., Sydes, T.A., Wescott, D.J., 2008. Recruitment dynamics of invasive species in rainforest habitats following Cyclone Larry. Aust. Ecol. 33, 495-502.
Ostertag, R., Scatena, F.N., Silver, W., 2003. Forest floor decomposition following hurricane litter inputs in several Puerto Rican forests. Ecosystems 61, 261-273.

Pérez-García, B., Mendoza, R.A., Sánchez-Coronado, M.E., Orozco-Segovia, A., 2007. Effect of light and temperature of germination of spores of four tropical fern species. Acta Oecol. 32, 172-179.

Portugal Loayza, A.B., del R., 2005. Effects of environmental factors and past land use on pteridophyte distributions in tropical forests. Masters Thesis. University of Puerto Rico, Rio Piedras. pp. 111.

Poulsen, A.D., Balslev, H., 1991. Abundance and cover of ground herbs in an Amazonian rain forest. J. Veg. Sci. 2, 315-322.

Proctor, G.R., 1989. Ferns of Puerto Rico and the Virgin Islands. Mem. New York Bot, Gard. 53, 1-389.

Ramírez-Trejo, M.d.R., Pérez-García, B., Orozco-Segovia, A., 2004. Analysis of fern spore banks from the soil of three vegetation types in the central region of Mexico. Am. J. Bot. 91, 682-688.

Richardson, B.A., Richardson, M.J., González, G., Shiels, A.B., Srivastava, D.S., 2010. A canopy trimming experiment in Puerto Rico: the response of litter invertebrate communities to canopy loss and debris deposition in a tropical forest subject to hurricanes. Ecosystems 13, 286-301.

Royo, A.A., Carson, W.P., 2006. On the formation of dense understory layers in forests worldwide: consequences and implications for forest dynamics, biodiversity, and succession. Can. J. For. Res. 36, 1345-1362.

Royo, A.A., Heartsill Scalley, T., Moya, S., Scatena, F.N., 2011. Non-arborescent vegetation trajectories following repeated hurricane disturbance: ephemeral versus enduring responses. Ecosphere 2, 1-17.

Scatena, F.N., Larsen, M.C., 1991. Physical aspects of Hurricane Hugo in Puerto Rico. Biotropica 23, 317-323.

Scatena, F.N., Silver, W., Siccama, T., Johnson, A., Sánchez, M.J., 1993. Biomass and nutrient content of the Bisley Experimental Watersheds, Luquillo Experimental Forest, Puerto Rico before and after Hurricane Hugo, 1989. Biotropica 25, 15-27.

Scatena, F.N., Moya, S., Estrada, C., Chinea, J.D., 1996. The first five years in the reorganization of aboveground biomass and nutrient use following Hurricane Hugo in the Bisley Experimental Watersheds, Luquillo Experimental Forest, Puerto Rico. Biotropica 28, 424-440.

Scatena, F.N., Blanco, J.F., Beard, K.H., Waide, R.B., Lugo, A.E., Brokaw, N., Silver, W.L., Haines, B.L., Zimmerman, J.K., 2012. Disturbance regime. In: Brokaw, N., Crowl, T.A., Lugo, A.E., McDowell, W.H., Scatena, F.N., Waide, R.B., Willig, M.R. (Eds.), A Caribbean Forest Tapestry, the Multidimensional Nature of Disturbance and Response, Oxford University Press, Oxford, pp. 164-200.

Sharpe, J.M., 1997. Leaf growth and demography of the rheophytic fern Thelypteris angustifolia (Willdenow) Proctor in a Puerto Rican rainforest. Plant Ecol. 130, 203-212.

Sharpe, J.M., 2005. Temporal variation in sporophyte fertility in Dryopteris intermedia and Polystichum acrostichoides (Dryopteridaceae: Pteridophyta). Fern Gaz. 17, 223-234.

Sharpe, J.M., 2010a. Long term monitoring of five uncommon tropical forest understory ferns in Puerto Rico. Indian Fern J. 27, 242-253.

Sharpe, J.M., 2010b. Responses of the mangrove fern Acrostichum danaeifolium Langsd. \& Fisch. (Pteridaceae, Pteridophyta) to disturbances resulting from increased soil salinity and Hurricane Georges at the Jobos Bay National Estuarine Research Reserve, Puerto Rico. Wetl. Ecol. Manag. 18, 57-68.

Sharpe, J.M., Mehltreter, K., 2010. Ecological insights from fern population dynamics. In: Mehltreter, K., Walker, L.R., Sharpe, J.M. (Eds.), Fern Ecology. Cambridge University Press, Cambridge, pp. 61-110.

Shiels, A.B., González, G., 2014. Understanding the key mechanisms of tropical forest responses to canopy loss and biomass deposition from experimental hurricane effects. Forest Ecol. Manage. 332, 1-10.

Shiels, A.B., Zimmerman, J.K., García-Montiel, D.C., Jonckheere, I., Holm, J., Horton, D., Brokaw, N., 2010. Plant responses to simulated hurricane impacts in a subtropical wet forest, Puerto Rico. J. Ecol. 98, 659-673.

Silva Matos, D.M., Belinato, T.A., 2010. Interference of Pteridium arachnoideum (Kaulf.) Maxon. (Dennstaedtiaceae) on the establishment of rainforest trees. Braz. J. Biol. 70, 311-316.

Siman, S.E., Sheffield, E., 2002. Polypodium vulgare plants sporulate continuously in a non-seasonal glasshouse environment. Am. Fern J. 92, 30-38.

Smith, R.F., 1970. Vegetation structure of the Puerto Rican rain forest. In: Odum, H.T., Pigeon, R.F. (Eds.), A Tropical Rain Forest: A study of Irradiation and Ecology at El Verde, Puerto Rico. Division of Technical Information, US Atomic Energy Commission, Washington, DC, pp. D103-D140.

Soil Survey Staff, 1995. Order 1 soil survey of the Luquillo Long-term ecological research grid, Puerto Rico. United States Department of Agriculture, Natural Resource Conservation Service, Lincoln, Nebraska.

Steeves, T.A., 1959. An interpretation of two forms of Osmunda cinnamomea. Rhodora 61, 223-230.

Uriarte, M., Canham, C.D., Thompson, J., Zimmerman, J.K., Brokaw, N., 2005. Seedling recruitment in a hurricane-driven tropical forest: light limitation, density-dependence and the spatial distribution of parent trees. J. Ecol. 93, 291-304.

Walker, L.R., 1994. Effects of fern thickets on woodland development on landslides in Puerto Rico. J. Veg. Sci 5, 525-532.

Walker, L.R., 2012. Biology of Disturbed Habitats. Oxford University Press, Oxford UK.

Walker, L.R., Sharpe, J.M., 2010. Ferns, disturbance and succession. In: Mehltreter, K., Walker, L.R., Sharpe, J.M. (Eds.), Fern Ecology. Cambridge University Press, Cambridge, pp. 177-219. 
Walker, L.R., Zimmerman, J.K., Lodge, D.J., Guzmán-Grajales, S., 1996. An altitudinal comparison of growth and species composition in hurricane-damaged forests in Puerto Rico. J. Ecol. 84, 87-889.

Walker, L.R., Landau, F.H., Velázquez, E., Shiels, A.B., Sparrow, A.D., 2010. Early successional woody plants facilitate and ferns inhibit forest development on Puerto Rican landslides. J. Ecol. 98, 625-635.

Walker, L.R., Shiels, A.B., Bellingham, P.J., Sparrow, A.D., Fetcher, N., Landau, F., Lodge, D.J., 2013. Changes in abiotic influences on seed plants and ferns during 18 years of primary succession on Puerto Rico landslides. J. Ecol. 101, 650-661.

Washington-Allen, R.A., Ramsey, R.D., West, N.E., Norton, B.E., 2008. Quantification of the ecological resilience of drylands using digital remote sensing. Ecol. Soc. 13, 33, <http://www.ecologyandsociety.org/vol13/iss1/art33/>.

Watson, J., Estes, J.A., 2011. Stability, resilience, and phase shifts in rocky subtidal communities along the wet coast of Vancouver Island, Canada. Ecol. Monogr. 81, 215-239.
Weaver, P.L., 2008. Dwarf forest recovery after disturbances in the Luquillo Mountains of Puerto Rico. Caribbean J. Sci. 44, 150-163.

Willig, M.R., Bloch, C., Covich, A.P., Hall, C.A.S., Lodge, D.J., Lugo, A.E., Silver W.L., Waide, R.B., Walker, L.R., Zimmerman, J.K., 2012. Long-term research in the Luquillo Mountains: synthesis and foundations for the future. In: Brokaw, N., Crowl, T.A., Lugo, A.E., McDowell, W.H., Scatena, F.N., Waide, R.B., Willig, M.R. (Eds.), A Caribbean Forest Tapestry, the Multidimensional Nature of Disturbance and Response. Oxford University Press, Oxford, pp. $361-442$.

Zimmerman, J.K., Willig, M.R., Walker, L.R., Silver, W.L., 1996. Introduction: disturbance and Caribbean ecosystems. Biotropica 28, 414-423.

Zimmerman, J.K., Wright, S.J., Calderón, O. Aponte Pagan, M., Paton, S. 2007. Flowering and fruiting phenologies of seasonal and aseasonal neotropical forests: the role of annual changes in irradiance. J. Trop. Ecol. 23, 231-251. 